\title{
Egg production by colonies of a gorgonian coral
}

\author{
Elizabeth A. Beiring*, Howard R. Lasker \\ Department of Biological Sciences, University at Buffalo, Buffalo, New York 14260, USA
}

\begin{abstract}
Reproductive success, the production and fertilization of gametes, is a key component of fitness. Among many colonial marine invertebrates, the production of gametes by a colony is a function of both gamete production per module (e.g., polyp, zooid) and the number of modules in the colony (i.e., colony size). We examined variance in gamete production per polyp and egg production per colony over a range of colony sizes, and the relationship between egg production and growth in the common Caribbean gorgonian Plexaura flexuosa. The number of polyps per colony and the average number of mature eggs per polyp both were greater among larger female colonies ( $>70 \mathrm{~cm}$ in height) than among smaller colonies $(<70 \mathrm{~cm})$, resulting in a 1 to 2 order of magnitude increase in whole colony egg release for the larger colonies. In a group of 24 colonies, $98 \%$ of the $9.2 \times 10^{6}$ eggs produced in one spawning event came from the 12 colonies taller than $70 \mathrm{~cm}$. Branch extension rates showed no relationship to colony size, but whole colony relative growth appears to decrease as colony size increases. This suggests that proportionately less energy is used for growth as a colony gets larger, and thus may be available for reproduction.
\end{abstract}

KEY WORDS: Reproduction - Growth - Invertebrates - Modular animals - Plexaura flexuosa

\section{INTRODUCTION}

An array of studies has examined the reproductive biology of benthic marine invertebrates in the context of life history strategies (e.g., Vance 1973, Harvell \& Grosberg 1988, Levitan 1995). Factors such as fertilization success and larval mortality have been considered important determinants of reproductive success (i.e., the production and fertilization of gametes). However, for the many marine invertebrates that exhibit clonal growth, the highly variable size of mature colonies can also lead to large differences in numbers of gametes produced. This in turn can have a tremendous effect on estimates of reproductive success among colonies and populations. To date, only a few studies have estimated egg production of whole colonies, and they have noted high levels of variance based on colony size (e.g., Babcock 1984, 1991, Coma et al. 1995, Hall \& Hughes 1996). Variance in gamete production among

\footnotetext{
- Present address: Office of Wetlands, Oceans, and Watersheds (4504F), U.S. Environmental Protection Agency, Ariel Rios Building, 1200 Pennsylvania Ave. NW, Washington, DC 20460,USA.E-mail: beiring.elizabeth@epa.gov
}

colonies can decrease effective population size because effective population size is inversely proportional to variance in reproductive success (e.g., Hughes et al. 1992). Furthermore, 2 studies have indicated that large colonies contribute disproportionately to egg production by whole populations (Babcock 1984, Coma et al. 1995).

Variance in the reproductive output of clonal taxa is primarily a function of the iterative production of modules, each of which may be capable of reproduction. Additional variability is associated with the integration of modules into physiologically connected colonies. For example, in many corals and other colonial animals all modules in a colony delay reproduction until the colony reaches a minimum size (e.g., Karlson 1986, Harvell \& Grosberg 1988, Coma et al. 1995). Additionally, gamete production per polyp increases as colony size increases among some coral species (e.g., Babcock 1991, Coma et al. 1995, Hall \& Hughes 1996). Delay in reproduction and increases in egg production per polyp with colony size may reflect greater availability of energy in general among larger colonies or a change in the allocation of energy from growth to reproduction (e.g., Hughes \& Jackson 1985, Kinzie \& Sarmiento 
1986, Hall \& Hughes 1996). Thus life history analyses of clonal organisms should incorporate data on the fecundity of modules and colonies, as well as the manner in which resources are distributed between fecundity and growth of the colonies.

The objectives of this study were (1) to document the reproductive cycle of Plexaura flexuosa, a common Caribbean gorgonian coral, and (2) to examine variance in gamete volume per polyp, egg praduction by whole colonies, and growth of branches and colonies. Using measurements of egg production per polyp, polyp density, and colony surface area within and across colonies, we (3) quantified the relationship between colony size and egg production, and (4) com- pared the relative contributions of colonies of various sizes to egg production by a population. Using measurements of branch extension and estimates of relative growth in whole colonies over a range of colony heights, we (5) examined the relationship between reproductive output and growth. Although we present data on the timing of both egg and spermary development, most of our discussion about reproductive output focuses on egg production. Eggs are more readily quantified than sperm, and although sperm density sometimes limits gorgonian reproductive success (Lasker et al. 1996), the number of eggs produced sets an upper limit for reproductive success.
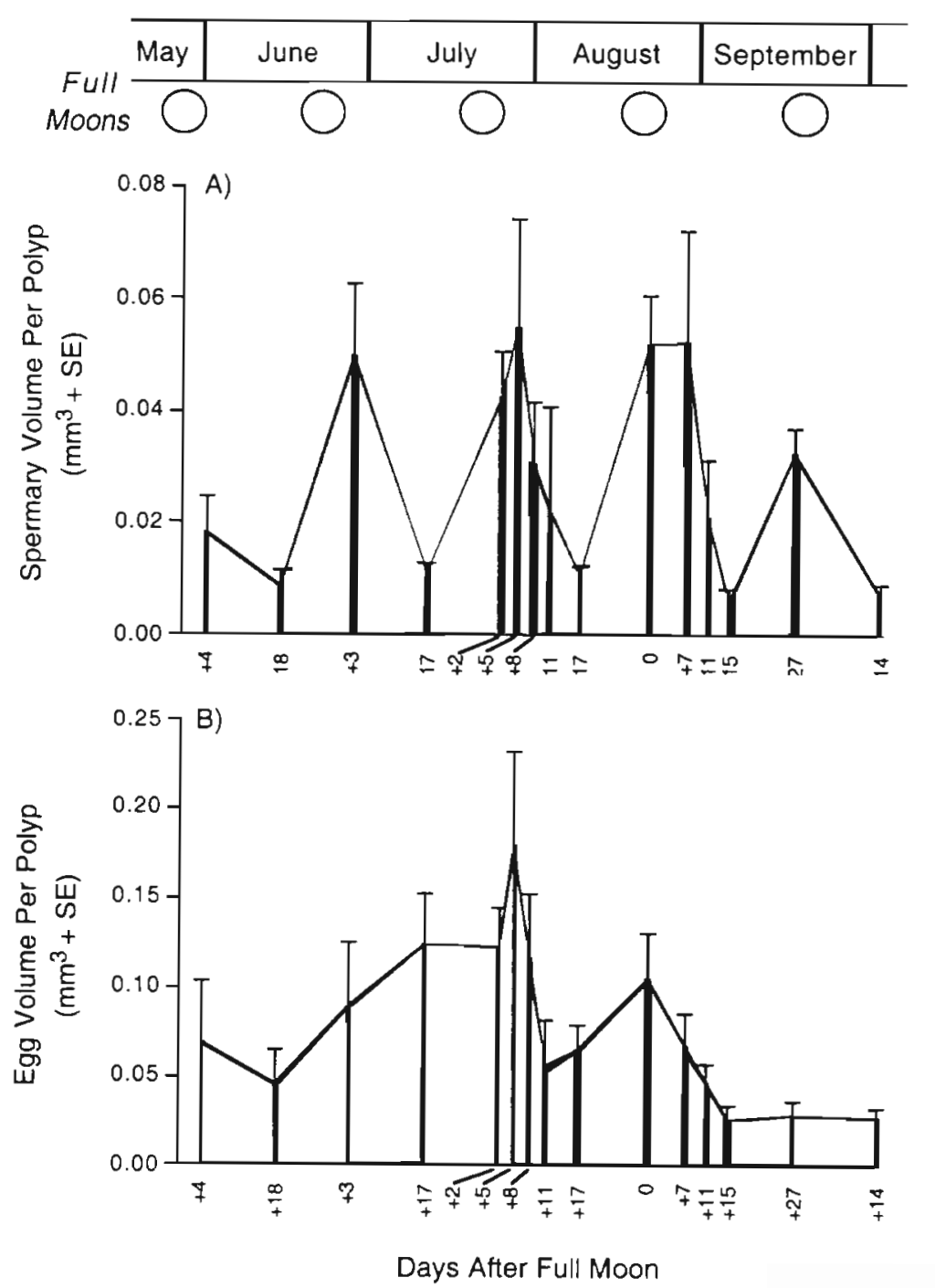

Fig. 1. Plexaura flexuosa. Average gamete volume $\left(\mathrm{mm}^{3}\right)$ per polyp (+SE) over 5 Junar cycles of the 1994 reproductive season for (A) 6 male and (B) 6 female colonies. Samples were taken on all dates labeled. Full moons were May 25, June 23, July 22, August 21, and September 19

\section{MATERIALS AND METHODS}

We assessed reproductive output and growth of Plexaura flexuosa colonies on patch reefs in the San Blas Islands, Panama. $P$. flexuosa is a gonochoric branching gorgonian coral common throughout the Caribbean (Bayer 1961, Goldberg 1973, Lasker \& Coffroth 1983). Unless otherwise stated, all samples were collected from colonies on Korbiski Reef, a patch reef 2 to $4 \mathrm{~m}$ deep (Korbiski-1 in Robertson 1987, Fig. 1). All P. flexuosa samples were preserved in $10 \%$ formalin in seawater immediately after collection, then rinsed in freshwater for $\sim 16 \mathrm{~h}$ and transferred to $70 \%$ ethanol before examination.

Reproductive cycle. A number of plexaurids, including Pseudoplexaura spp., Plexaurella sp., and the congeners Plexaura homomalla and Plexaura kuna, spawn shortly after the summer full moons (Brazeau \& Lasker 1989, Coma \& Lasker 1997, pers. obs.). In order to determine the spawning cycle of Plexaura flexuosa, gamete volumes in polyps from 6 male and 6 female colonies were followed over 5 lunar cycles during the 1994 summer. One growing tip (i.e., $1^{\circ}$ branch) from each colony was taken approximately biweekly from May 29, 1994 to October 3, 1994, and more frequently (every 3 to $4 \mathrm{~d}$ ) during July and August when we suspected spawning would occur.

Average gamete volume per polyp for each branch was determined by counting and measuring the diameters of all eggs (or spermaries) in 10 polyps using a binocular dissecting microscope fitted with an eyepiece micrometer. Polyps were chosen randomly from a segment of the branch between 2 and 
$3 \mathrm{~cm}$ from the branch tip. Gamete diameters were converted to volumes (assuming gametes were spherical), summed within each polyp, then averaged over the 10 polyps in each sample. Eggs were pink and up to $\sim 750 \mu \mathrm{m}$ in diameter; spermaries were gray to beige, and up to $\sim 450 \mu \mathrm{m}$ in diameter. Female polyps seldom contained more than 4 large $(\geq 400 \mu \mathrm{m})$ eggs, while male polyps contained as many as 22 spermaries.

Variability in egg production. Egg production by a polyp may vary depending on the polyp's location within a colony or on the size of the colony itself. To examine within-colony variability, average egg volume per polyp was determined for branches at different distances from the branch tips. Branches were classified according to branch order (sensu Brazeau \& Lasker 1988), and 10 polyps were dissected from the central $1 \mathrm{~cm}$ portion of $1^{\circ}$ source, $1^{\circ}$ tributary, $2^{\circ}$ and $3^{\circ}$ branches, and from pieces of the colony base. One branch of each type was sampled from each of 8 female colonies (50 to $81 \mathrm{~cm}$ tall). Samples were collected 1 to 2 d after the July 1994 full moon ( 4 to 5 d before spawning). Egg volume data were heteroscedastic and could not be transformed to normality; therefore differences among branch orders were tested using Friedman's 2 -way (colony $\times$ branch order) ANOVA by ranks.

To examine variability in egg production per polyp among colonies of different sizes, one $1^{\circ}$ branch was taken from each of 24 female colonies ranging from 33 to $107 \mathrm{~cm}$ in height. Samples were collected 4 to $5 \mathrm{~d}$ before the July 1994 full moon $(\sim 10$ to $11 \mathrm{~d}$ before spawning). Egg volume per polyp for each branch was determined by counting and measuring all eggs in 10 polyps, converting egg diameters to volumes, summing the egg volumes within each polyp, then averaging the total volume across the 10 polyps. Polyps were chosen randomly from a segment of the branch between 2 and $3 \mathrm{~cm}$ from the branch tip. Regression analysis was used to test the relationship between egg volume per polyp and colony height.

Release of eggs. The total number of eggs released during a spawning event was calculated for 24 female colonies using counts of mature eggs per polyp, estimates of the percent of mature eggs released per spawning event, and estimates of the number of polyps per colony of a given size, as described below.

Size and number of mature eggs per polyp: To determine the size of mature eggs (i.e., those that could be spawned), 1 clump of primary and secondary branches was collected from each of 2 female colonies and kept in separate running-seawater aquaria during the August 1995 spawning. Over 200 eggs spawned from these branches on August 19 and 20 were collected, preserved in 5\% formalin, and their diameters measured.
The average number of mature eggs per polyp was determined for primary branches from 24 female colonies ranging from 33 to $107 \mathrm{~cm}$ tall (see 'Variability in egg production' above). Because these samples were collected $\sim 10$ to $11 \mathrm{~d}$ before spawning, eggs had not yet reached their maximum size. To correct for this, a comparison was made of egg sizes from branches of 6 colonies collected $\sim 10$ and $\sim 1$ d before spawning (10 polyps per colony per sampling event).

Eggs released during spawning: The percent of mature eggs released during a spawning event was estimated by comparing the average number of mature eggs per polyp in branches that were collected from 6 female colonies before and after spawning events in both July and August 1994 (1 branch per colony per sampling event; 10 polyps per branch). Samples for 'before spawning' were collected 0 to $5 \mathrm{~d}$ after the full moon. Samples for 'after spawning' were collected 15 to $17 \mathrm{~d}$ after the full moon.

Polyps per colony: Polyp densities on branches of 8 female colonies (50 to $81 \mathrm{~cm}$ tall) were determined from counts of the number of polyps within measured areas of 5 branch orders $\left(1^{\circ}\right.$ source, $1^{\circ}$ tributary, $2^{\circ}$ and $3^{\circ}$ branches, and a piece from the colony base). For $1^{\circ}$, $2^{\circ}$, and $3^{\circ}$ branches, the measured areas were approximately $1 \mathrm{~cm}$ long and located at the center of each branch; branch diameter at the ends of the $1 \mathrm{~cm}$ section was measured and surface area computed using the average diameter (range for all branches was 0.99 to $2.26 \mathrm{~cm}^{2}$ ). Polyp density within an area of approximately $1 \times 2 \mathrm{~cm}$ (range 1.64 to $3.33 \mathrm{~cm}^{2}$ ) was measured at the base of the colony. Polyp densities were compared using a 2-way ANOVA without replication.

In order to estimate the number of polyps in an entire colony, the polyp density measures were multiplied by the total surface area of branches of each order. Total surface areas for the different branch orders were estimated for 10 colonies (33 to $107 \mathrm{~cm}$ in height) from Tiantupo Reef (Tiantupo-1 in Robertson 1987). All branches on each colony were counted and categorized by branch order. Length (to nearest mm using a flexible clear ruler) and diameter (to nearest $0.1 \mathrm{~mm}$ using calipers) were measured on ten $1^{\circ}, 2^{\circ}$, and $3^{\circ}$ branches and on all higher order branches. Surface area $\left(\mathrm{SA}, \mathrm{cm}^{2}\right.$ ) of each branch was calculated $(\pi \mathrm{dh})$. Average SA and polyp density for each branch order were used to calculate whole colony polyp number

For purposes of prediction, a regression was fitted between number of polyps and colony volume (i.e., the volume of a box fitted around the colony calculated from colony maximum height, width, and depth measured to nearest $\mathrm{cm}$ ) for these 10 colonies. Because this relationship was highly significant, the resulting regression equation was used to estimate the number of polyps on another group of 24 female colonies using 


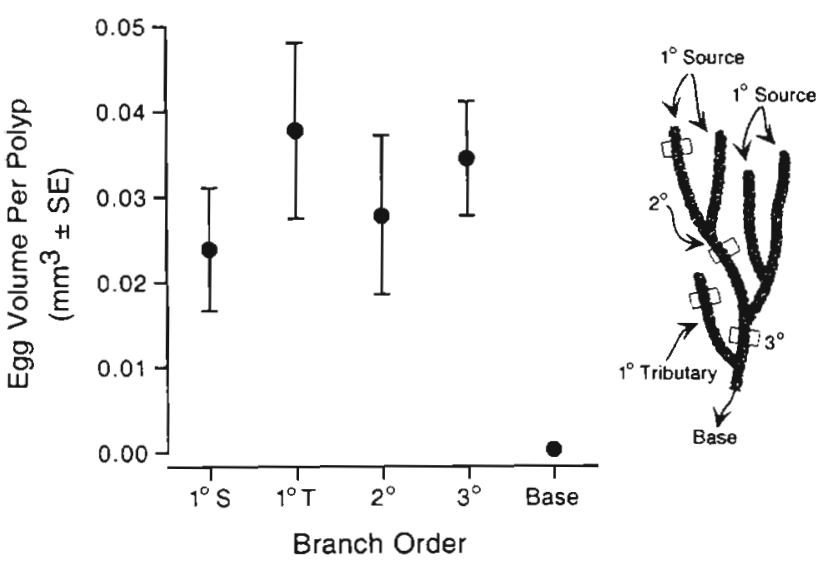

Fig. 2. Plexaura flexuosa. Average egg volume $\left(\mathrm{mm}^{3}\right)$ per polyp $( \pm \mathrm{SE}$ ) across 5 branch orders in 8 colonies (10 polyps per branch order per colony). S: source, T: tributary

measurements of their volume (i.e., height $x$ width $x$ depth). The number of eggs released during spawning by each of the 24 colonies was estimated by multiplying (1) the number of polyps in the colony by (2) the number of mature eggs produced per polyp by (3) the percentage of mature eggs in a polyp released during a spawning event.

Growth rates. Growth rates were determined for 29 colonies on 3 patch reefs (Tiantupo-1, Porvenir-17, and Aguadargana-1 in Robertson 1987). Our measure of growth was the change in length of primary branches. On each colony, a section of 11 to 21 primary branches was identified and sketched to allow relocation. The length of each primary branch was measured $( \pm 1 \mathrm{~mm})$ in 1995 and again in 1996 (297 to 355 d). Because the branches measured on each colony were adjacent to one another, their growth rates may not have been independent. Therefore, we used averages for each colony in our statistical analyses.

\section{RESULTS}

\section{Reproductive cycle}

Plexaura flexuosa spawning events during the summer of 1994 can be identified by precipitous drops in gamete volume per polyp that occurred after the full moons (Fig 1). Evidence of spawning was particularly striking among male colonies (Fig. 1A). All 6 male colonies spawned after the June 23, July 22, August 21, and September 17, 1994, full moons. Four of the 6 males also may have spawned after the May 25 full moon. Fine-scale sampling after the July 22 and August 21 full moons indicated that spawning started 6 or $7 \mathrm{~d}$ after the full moon and ended 11 to $15 \mathrm{~d}$ after the full moon.

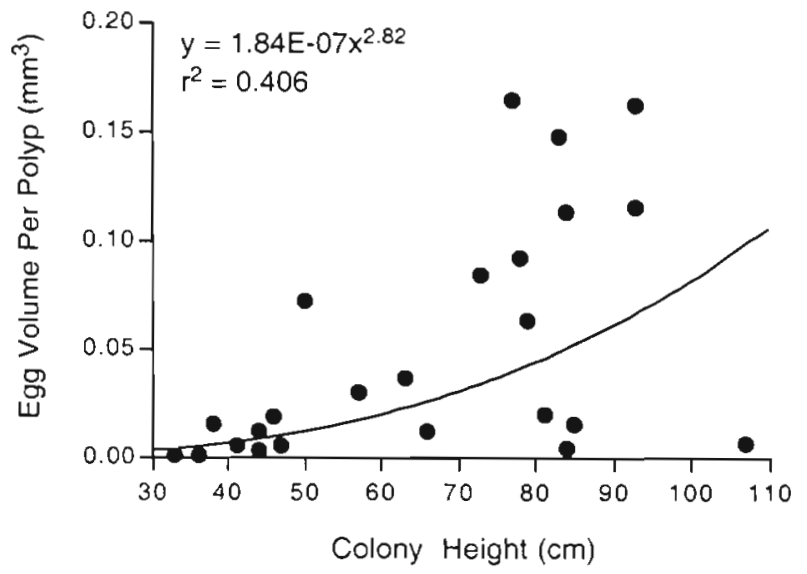

Fig. 3. Plexaura flexuosa. Average egg volume $\left(\mathrm{mm}^{3}\right)$ per polyp as a function of colony height in 24 colonies ( 10 polyps per colony)

Changes in the average number of mature eggs ( $\geq 500 \mu \mathrm{m}$; see below) per polyp over time showed that 5 of the 6 females spawned heavily during only 1 or 2 lunar cycles (after the July and/or August full moons; results not shown), in contrast to the male colonies, each of which spawned 4 or 5 times over the 5 lunar cycles.

Our sampling scheme was based on our familiarity with the spawning of other plexaurids, and it is possible that Plexaura flexuosa spawned outside of our summer sampling period. However, the shape of the egg volume per polyp curve (Fig. 1B), with its peak in July, indicates that there is seasonality to $P$. flexuosa spawning, and that if spawning occurs outside this time period, it is likely to be light. Furthermore, average egg volumes of samples taken on February 2, 1995 ( $4 \mathrm{~d}$ before the full moon), were similar to those of postspawning samples from October 3, 1994, again suggesting that spawning did not occur outside the summer months.

\section{Variability in egg production per polyp}

There was no significant difference in average egg volume per polyp among $1^{\circ}, 2^{\circ}$, and $3^{\circ}$ branches (Fig. 2; Friedman's $X^{2}=4.95 ; p=0.176$ ). There was a virtual absence of gametes in polyps from the bases of colonies, however, which resulted in a significant difference when these samples were included in the analysis (Fig. 2; Friedman's $X^{2}=19.3 ; p=0.0007$ ).

Colony height had a significant effect on egg volume per polyp (Fig. $3 ; \mathrm{r}^{2}=0.406 ; F_{1.22}=15.1 ; \mathrm{p}=0.0008$ ). Although every polyp examined except 1 contained at least $1 \mathrm{egg}$, there were differences in the percentage of polyps bringing eggs to maturity. Of the 120 polyps examined 


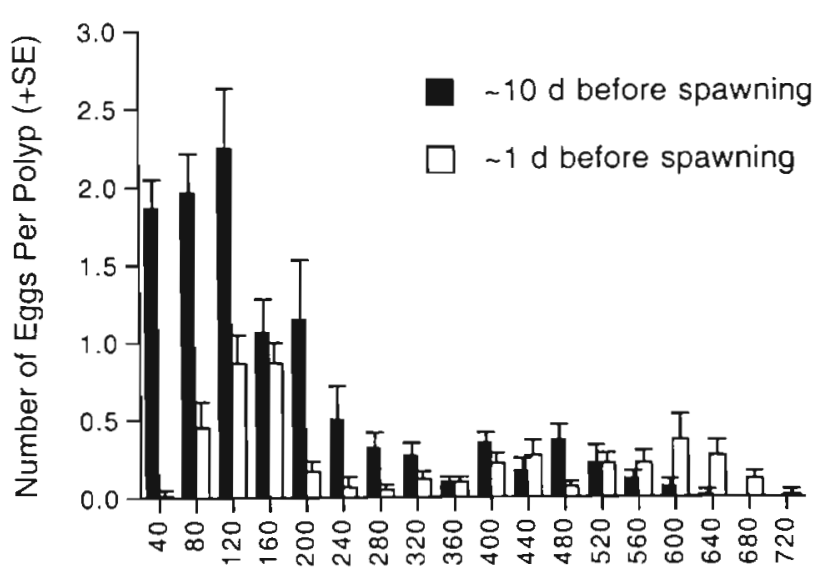

Fig. 4. Plexaura flexuosa. Comparison of egg size class distributions in 6 colonies $\sim 10$ and -1 d before spawning ( 10 polyps per colony per sampling date)

from the 12 small colonies $(<70 \mathrm{~cm})$, only $13 \%$ contained large $(\geq 400 \mu \mathrm{m})$ eggs, with an average of 1.3 large eggs per polyp among these polyps. Of the 120 polyps from the 12 large colonies $(>70 \mathrm{~cm}), 55 \%$ contained at least 1 large egg, with an average of 1.9 polyp $^{-1}$.

\section{Release of eggs}

Size and number of mature eggs per polyp

Spawned eggs ranged in size from 533 to $667 \mu \mathrm{m}$ in diameter, with an average of $597 \pm 27 \mu \mathrm{m}( \pm \mathrm{SD})$. A comparison of egg sizes from $\sim 10$ and $\sim 1 \mathrm{~d}$ before spawning in 6 female colonies showed that the number of eggs $\geq 400 \mu \mathrm{m}$ on the earlier date roughly corresponded to the number of eggs $\geq 500 \mu \mathrm{m}$ on the later date (Fig. 4). Therefore, for samples collected $\sim 10 \mathrm{~d}$ before spawning, we counted all eggs $\geq 400 \mu \mathrm{m}$ as 'mature eggs' that could be released that month. The number of mature eggs per polyp in samples from 24 colonies collected $\sim 10 \mathrm{~d}$ before spawning ranged from 0 to 2.2, and increased with increasing colony size (Fig. 5A).

\section{Eggs released during spawning}

Branches collected prior to spawning contained an average of $1.09 \pm 0.73$ mature eggs per polyp $\left( \pm \mathrm{SD}_{i}\right.$ range among branches 0.1 to 2.6; data not shown). Branches collected after spawning had an average of $0.17 \pm 0.24$ mature eggs per polyp $( \pm \mathrm{SD}$; range 0.0 to 0.8 ; data not shown). This observation indicates that $84 \%$ of the mature eggs present in pre-spawning samples were released.
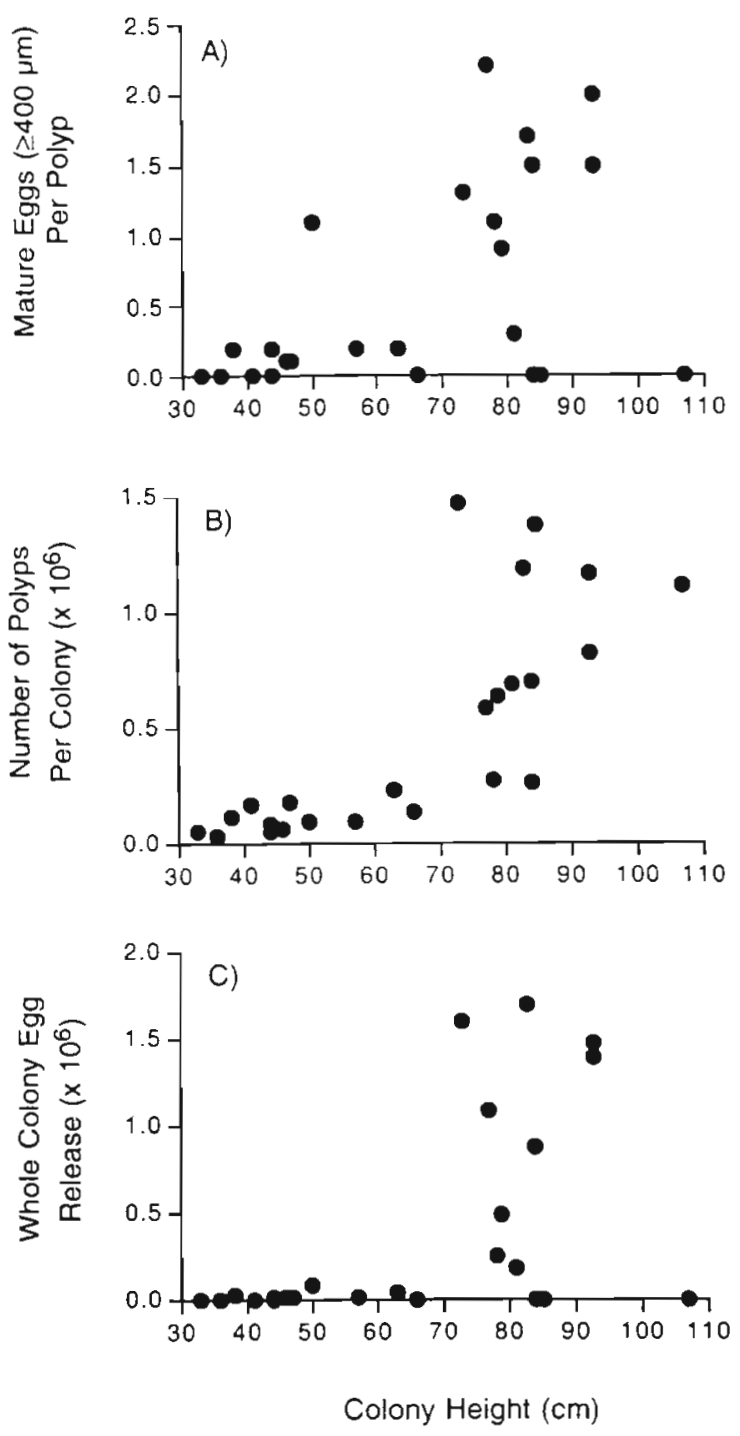

Fig. 5. Plexaura flexuosa. (A) Per polyp fecundity, (B) whole colony polyp count, and (C) whole colony egg release by colony height for 24 colonies

Polyps per colony

Total branch counts (all branch orders) of 10 colonies ranged from 117 branches for a $37 \mathrm{~cm}$ tall colony to 3861 branches for a $107 \mathrm{~cm}$ tall colony (Table 1). Total surface area ranged from 0.104 to $6.73 \mathrm{~m}^{2}$ (Table 1). Primary, $2^{\circ}$, and $3^{\circ}$ branches together accounted for an average of $92 \%$ of total colony surface area (range 87 to $97 \%$; Table 1).

Polyp density did not differ across branch orders (ANOVA without replication, $F_{4,28}=2.36, \mathrm{p}=0.078$ ) and averaged $50 \pm 8$ polyps $\mathrm{cm}^{-2}( \pm \mathrm{SD})$. Using this density, the total number of polyps per colony ranged from $5.18 \times$ $10^{4}(37 \mathrm{~cm}$ tall colony $)$ to $3.36 \times 10^{6}(107 \mathrm{~cm}$ tall colony; Table 1). Colony volume (colony height $x$ width $x$ 
Table 1 Surface area and polyp number estimates for 10 Plexaura flexuosa colonies. Volume given as colony width $\times$ depth $x$ helght. Total number of polyps calculated using 50 polyps $\mathrm{cm}^{-2}$ (see text). Total number and \% of total surface area given for each branch order

\begin{tabular}{|c|c|c|c|c|c|c|c|c|c|c|c|c|}
\hline \multirow{2}{*}{$\begin{array}{l}\text { Col- } \\
\text { ony }\end{array}$} & \multirow{2}{*}{$\begin{array}{l}\text { Height } \\
\text { (cm) }\end{array}$} & \multirow{2}{*}{$\begin{array}{c}\text { Volume } \\
\qquad\left(\mathrm{m}^{3}\right)\end{array}$} & \multirow{2}{*}{$\begin{array}{c}\text { Total } \\
\text { branch } \\
\text { length } \\
(\mathrm{cm})\end{array}$} & \multirow{2}{*}{$\begin{array}{c}\text { Surface } \\
\text { area } \\
\left(\mathrm{m}^{2}\right)\end{array}$} & \multirow{2}{*}{$\begin{array}{l}\text { Total } \\
\text { no. of } \\
\text { polyps }\end{array}$} & \multicolumn{7}{|c|}{ No. of branches ( $\%$ of total surface area) for each branch order } \\
\hline & & & & & & $1^{\circ}$ & $2^{\circ}$ & $3^{\circ}$ & $4^{\circ}$ & $5^{\circ}$ & $6^{\circ}$ & $7^{\circ}$ \\
\hline 1 & 33 & 0.0203 & 861 & 0.114 & 56800 & $103(52)$ & $33(27)$ & $9(18)$ & $3(3)$ & 0 & 0 & 0 \\
\hline 2 & 37 & 0.0178 & 638 & 0.104 & 51800 & $78(45)$ & $29(35)$ & $8(12)$ & $2(7)$ & 0 & 0 & 0 \\
\hline 3 & 42 & 0.0194 & 782 & 0.129 & 64300 & $95(51)$ & $36(27)$ & $9(15)$ & $3(7)$ & 0 & 0 & 0 \\
\hline 4 & 42 & 0.0464 & 1040 & 0.167 & 83500 & $171(42)$ & $58(32)$ & $15(12)$ & $6(10)$ & $2(3)$ & 0 & 0 \\
\hline 5 & 52 & 0.0598 & 1940 & 0.307 & 154000 & $173(65)$ & $48(18)$ & $14\{10\}$ & $5(6)$ & $1(2)$ & 0 & 0 \\
\hline 6 & 66 & 0.247 & 6830 & 1.06 & 528000 & $760(52)$ & $225(31)$ & $65(9)$ & $21(4)$ & $7(3)$ & $3(1)$ & $1(0.03)$ \\
\hline 7 & 70 & 0.549 & 6010 & 1.13 & 566000 & $506(61)$ & $132(23)$ & $37(8)$ & $11(4)$ & $4(2)$ & $1(1)$ & 0 \\
\hline 8 & 85 & 0.495 & 7110 & 1.28 & 642000 & $540(61)$ & $153(27)$ & $44(6)$ & $14(3)$ & $5(2)$ & $2(1)$ & 0 \\
\hline 9 & 96 & 0.288 & 3890 & 0.755 & 377000 & 444 (51) & $134(16)$ & $39(20)$ & $9(4)$ & $4(4)$ & $2(4)$ & 0 \\
\hline 10 & 107 & 2.25 & 36200 & 6.73 & 3360000 & $2681(65)$ & $834(18)$ & $245(10)$ & $78(4)$ & $15(1)$ & $6(1)$ & $2(1)$ \\
\hline
\end{tabular}

depth) was a good predictor of total number of polyps $\left(\mathrm{r}^{2}\right.$ $\left.=0.988 ; F_{i, 8}=685 ; \mathrm{p}=0.0001\right)$, yielding the equation:

Polyp number $=1.46 \times 10^{6}$ colony volume $\left(\mathrm{m}^{3}\right)+3960$

\section{Whole colony egg release}

Colony volume, and therefore polyp count (estimated using Eq. 1), rose dramatically after a colony reached $-70 \mathrm{~cm}$ in height (Fig. $5 \mathrm{~B}$ ) The average number of polyps in colonies less than $70 \mathrm{~cm}$ tall was $104000 \pm 58900$ (mean $\pm \mathrm{SD}$ ); the average number of polyps in colonies greater than $70 \mathrm{~cm}$ was $852000 \pm$ 403000 (mean \pm SD) - over an 8-fold increase. Similarly, the number of mature eggs per polyp (Fig. 5A) increased in colonies greater than $70 \mathrm{~cm}$, with colonies less than $70 \mathrm{~cm}$ averaging $0.18 \pm 0.30$ mature eggs per polyp (mean $\pm \mathrm{SD}$ ), and colonies greater than $70 \mathrm{~cm}$

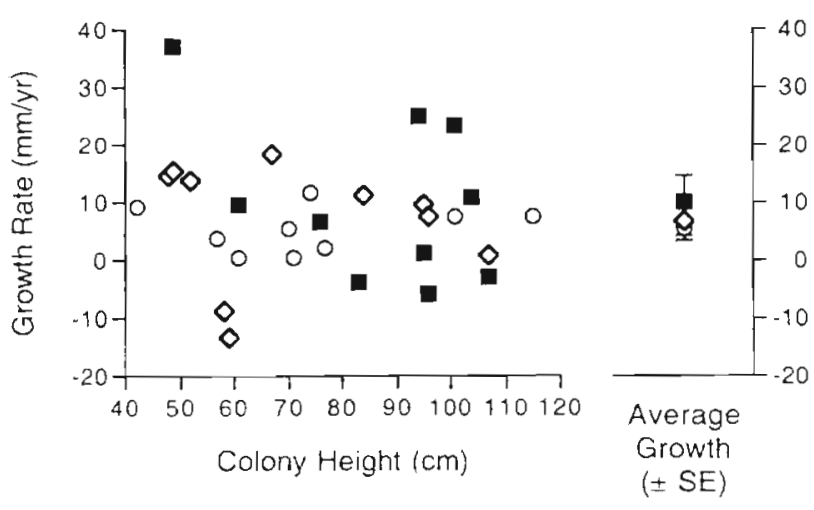

Fig. 6. Plexaura flexuosa. Average branch growth rate $\left(\mathrm{mm} \mathrm{yr}^{-1}\right)$ by colony height for 29 colonies on 3 reefs and average growth rate per reef $( \pm S E)$ averaging $1.0 \pm 2.2$ (mean $\pm \mathrm{SD}$ ) - a 6 -fold difference. Consequently, whole colony egg release number of polyps multiplied by number of mature eggs per polyp) increased dramatically after colony height reached $70 \mathrm{~cm}$, and ranged from 0 to $1.69 \times 10^{6}$ eggs per colony per spawning event (Fig. 5C)

\section{Growth rates}

Average branch growth rates varied tremendously among colonies, ranging from -13.3 to $+37.3 \mathrm{~mm} \mathrm{yr}^{-1}$ (Fig. 6). Negative growth rates reflect loss of tissue, most likely due to predation by the gastropods Cyphoma spp. and the polychaete Hermodice carunculata. (Plexaura flexuosa is not known to fragment like its congener $P$. kuna [pers. obs.].) There was no relationship between colony size and branch growth rate (Tiantupo: $\mathrm{r}^{2}=0.198, F=1.97, \mathrm{p}=0.20$; Porvenir17: $r^{2}=0.007, F=0.056, p=0.82 ;$ Aguadargana: $r^{2}=$ $0.028, F=0.204, p=0.67$ ). There also was no difference in branch growth rate among the 3 reefs $\left(F_{2,26}=0.506\right.$; $\mathrm{p}=0.61)$. Branch growth rate across all colonies was $7.7 \pm 3.4 \mathrm{~mm} \mathrm{yr}^{-1}$ (avera.ge $\pm \mathrm{SE}$ ).

As in other gorgonians (Coma 1994), most growth in Plexaura flexuosa probably occurs in $1^{\circ}$ branches. Because there appears to be no difference in $1^{\circ}$ branch growth rate across colony size for $P$. flexuosa, the number of $1^{\circ}$ branches divided by total linear length of a colony represents its relative growth rate. Plotting this ratio against colony height for the 10 colonies in Table 1 shows that there are significantly fewer growing tips per linear $\mathrm{cm}$ of colony tissue as colony height increases (Fig. 7; $r=-0.636, p=0.049$ ). Assuming that there are no systematic differences in $1^{\circ}$ branch 
growth rates throughout a colony (but see Kim 1996), relative growth decreases as colonies get larger.

\section{DISCUSSION}

\section{Colony size and consequences for populations}

Large Plexaura flexuosa colonies (>70 cm in height) produced on average 6 times more mature eggs per polyp than smaller colonies (Fig. 5A), and they had on average 8 times more polyps than smaller colonies (Fig. 5B). These differences in colony size and egg production per polyp resulted in a dramatic increase in whole colony egg release for colonies over $70 \mathrm{~cm}$ tall (Fig. 5C). Among colonies with mature eggs, those that were 33 to $66 \mathrm{~cm}$ tall released $10^{3}$ to $10^{4}$ eggs per colony per spawning event, while those that were 73 to $107 \mathrm{~cm}$ tall released $10^{5}$ to $10^{6}$ eggs per colony per spawning event. Of the estimated $9.2 \times 10^{6}$ eggs released by these 24 females during 1 spawning event, $9.0 \times 10^{6}$ came from the 12 colonies over $70 \mathrm{~cm}$ tall. In other words, $98 \%$ of the eggs were produced by only half of the colonies.

On 3 other reefs in the San Blas region, female colonies taller than $70 \mathrm{~cm}$ comprised 23,38 , and $49 \%$ of the female populations (Beiring 1997). Using average colony egg production values from the 24 colonies discussed above (15500 eggs for colonies $<70 \mathrm{~cm}$ and 749000 eggs for larger colonies), large colonies produce 93 to $98 \%$ of the eggs released on these 3 reefs. Therefore, the vast majority of eggs from these reefs are produced by a relatively small subset of the population.

In the 2 other studies where whole population egg production has been estimated, similar results have been reported. Coma et al. (1995) found that colonies of the Mediterranean gorgonian Paramuricea clavata taller than $40 \mathrm{~cm}$ comprised only $3 \%$ of the population yet contributed approximately $40 \%$ of the female gametes and $33 \%$ of the male gametes. For the scleractinian Goniastrea aspera, Babcock (1984) reported that colonies greater than $6 \mathrm{~cm}$ in mean radius comprised less than $22 \%$ of the population but contributed approximately $80 \%$ of total annual egg production. Although they did not measure egg production, Potts et al. (1985) found similar results for living surface area; of 65 colonies of 7 Porites species measured, $50 \%$ of the living surface area came from only 6 colonies.

These results indicate that population size alone, without reference to colony size structure, may be a poor predictor of population egg production and reproductive success. The huge variance in egg production among coral colonies leads to a much lower effective population size than predicted by a simple census of colonies (Hughes et al. 1992).

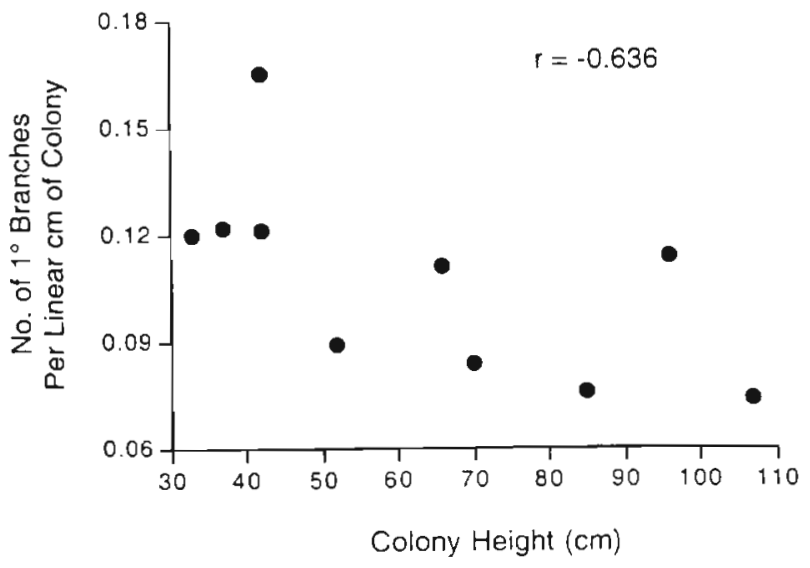

Fig. 7. Plexaura flexuosa. Relationship between colony height and the number of $1^{\circ}$ branches per linear $\mathrm{cm}$ of colony for 10 colonies

\section{Reproduction, growth, and colony size}

Reproduction and growth are commonly represented as processes competing for limited resources (e.g., Jackson \& Hughes 1985). The relationship is considerably more complex among clonal animals, where clonal growth can enhance reproduction by generating additional reproductive modules.

Delay in reproduction until a minimum colony size is reached is a trait common to many colonial invertebrates (e.g., Harvell \& Grosberg 1988, Brazeau \& Lasker 1989, 1990. Keough 1989, Babcock 1991, Soong \& Lang 1992, Van Veghel \& Kahmann 1994, Coma et al. 1995, Fan \& Dai 1995, Hall \& Hughes 1996; see also review by Harrison \& Wallace 1990). Most Plexaura flexuosa colonies become reproductive between 20 and $30 \mathrm{~cm}$ in height (Beiring 1997). Once reproduction began, reproductive output of individual $P$. flexuosa polyps increased with increasing colony size (Figs. $3 \&$ 5A). Similar findings have also been reported among hard corals (Rinkevich \& Loya 1979, Kojis \& Quinn 1981, 1985, Babcock 1984, 1991, Van Veghel \& Kahmann 1994, Hall \& Hughes 1996) and other soft corals (Brazeau \& Lasker 1990, Coma et al. 1995).

The relationship between reproductive output and growth rate is ambiguous. Absolute linear growth rates (i.e., branch extension rates) did not change with colony size (Fig. 6), similar to many other anthozoans (e.g., Kinzie \& Sarmiento 1986, Hughes \& Connell 1987, Babcock 1991, Yoshioka \& Yoshioka 1991, Coma 1994, Goh \& Chou 1995, but see Chornesky \& Peters 1987). However, there were fewer growing tips, and presumably less annual extension, per linear $\mathrm{cm}$ of colony with increasing colony height (Fig. 7), and therefore, on a relative or per polyp basis, less energy is invested in growth as a colony gets bigger (Connell 
1973. Hughes \& Jackson 1985, Hughes \& Connell 1987, Soong \& Lang 1992, Hall \& Hughes 1996).

It is possible that the delay in reproduction and reduced polyp fecundity in smaller colonies are consequences of greater resource allocation to growth at smaller sizes (Kojis \& Quinn 1981, Szmant 1986, Soong 1993, Ward 1995, Hall \& Hughes 1996). Because mortality is invariably greater for smaller coral colonies, such an allocation would allow colonies to grow quickly out of the more vulnerable smaller size classes (e.g., Connell 1973, Hughes \& Jackson 1985, Jackson \& Hughes 1985, Babcock 1991). However, less energy used for growth among large colonies does not necessarily translate into greater resource availability for reproduction. In branching corals, for instance, there may be a decrease in energy captured per polyp as a colony gets larger due to an increased percentage of interior branches with less access to water-borne nutrients and light (Holloran 1986, Kim \& Lasker 1997). It remains to be determined whether a decrease in relative growth reflects a change in allocation or a decrease in per polyp resource capture.

Acknowledgements. Support for this study was provided by Lerner Gray and Sigma Xi to E.A.B. and by the National Science Foundation (OCE 9217014) to H.R.L. We thank the Kuna Nation for permission to work in the San Blas and the Smithsonian Tropical Research Institute for logistical support. Contributions of D. A. Brazeau, M. A. Coffroth, R. Coma, T. L. Goulet, T Insalaco, K. Kim, R. Tapia, S. Santos, W. Kapela, and T. Swain to this study are gratefully acknowledged. This work was part of the E.A.B.'s doctoral dissertation and does not necessarily reflect the opinions of the Environmental Protection Agency.

\section{LITERATURE CITED}

Babcock RC (1984) Reproduction and distribution of two species of Goniastrea (Scleractinia) from the Great Barrier Reef Province. Coral Reefs 2:187-195

Babcock RC (1991) Comparative demography of three species of scleractinian corals using age- and size-dependent classification. Ecology $61: 225-244$

Bayer FM (1961) The shallow water octocorallia of the West Indian region. Nijhoff, The Hague

Beiring EA (1997) Life history and reproductive success of a broadcast-spawning gorgonian coral and implications for conservation biology. PhD thesis, State University of New York at Buffalo

Brazeau DA, Lasker HR (1988) Inter- and intraspecific variation in gorgonian colony morphology quantifying branching patterns in arborescent animals. Coral Reefs 7 : $139-143$

Brazeau DA, Lasker HR (1989) The reproductive cycle and spawning in a Caribbean gorgonian. Biol Bull 176:1-7

Brazeau DA, Lasker HR (1990) Sexual reproduction and external brooding by the Caribbean gorgonian Briareum asbestinum. Mar Biol 104:465-474

Chornesky EA, Peters EC (1987) Sexual reproduction and colony growth in the scleractinian coral Porites astreoides. Biol Bull 172:161-177
Coma R (1994) Energy budget assessment of two benthic marine cnidarians. PhD thesis, University of Barcelona

Coma R, Lasker HR (1997) Small-scale heterogeneity of fertilization success in a broadcast spawning octocoral. J Exp Mar Biol Ecol 214:107-120

Coma R, Zabala M, Gili JM (1995) Sexual reproductive effort in the Mediterranean gorgonian Paramuricea clavata. Mar Ecol Prog Ser 117:185-192

Connell JH (1973) Population ecology of reef-building corals. In: Jones OA, Endean R (eds) Biology and geology of coral reefs. Academic Press, New York, p 205-245

Fan TY, Dai CF (1995) Reproductive ecology of the scleractinian coral Echinopora lamellosa in northern and southern Taiwan. Mar Biol 123:565-572

Goh NKC, Chou LM (1995) Growth of five species of gorgonians (sub-class Octocorallia) in the sedimented waters of Singapore. PSZN I: Mar Ecol 16:337-346

Goldberg WM (1973) The ecology of the coral-octocoral communities off the southeast Florida coast: geomorphology, species composition, and zonation. Bull Mar Sci 23:465-488

Hall VR, Hughes TP (1996) Reproductive strategies of modular organisms: comparative studies of reef-building corals. Ecology 77:950-963

Harrison PL, Wallace CC (1990) Reproduction, dispersal, and recruitment of scleractinian corals. In: Dubinsky $Z$ (ed) Ecosystems of the world. Elsevier, Amsterdam, p 133-207

Harvell CD, Grosberg RK (1988) The timing of sexual maturity in clonal animals. Ecology 69:1855-1864

Holloran MK (1986) The relationship between colony size and larva production in the reef coral Pocillopora damicornis. In: Jokiel PL, Richmond RH, Rogers RA (eds) Coral reef population biology. Hawaii Inst Mar Biol Tech Rep, Honolulu, p $167-169$

Hughes TP, Connell JH (1987) Population dynamics based on size or age? A reef-coral analysis. Am Nat 129:818-829

Hughes TP, Jackson JBC (1985) Population dynamics and life histories of foliaceous corals. Ecol Monogr 55:141-166

Hughes TP, Ayre D, Connell JH (1992) The evolutionary ecology of corals. Trends Ecol Evol 7:292-295

Jackson JBC, Hughes TP (1985) Adaptive strategies of coralreef invertebrates. Am Sci 73:265-274

Karlson RH (1986) Disturbance, colonial fragmentation, and size-dependent life history variation in two coral reef cnidarians. Mar Ecol Prog Ser 28:245-249

Keough MJ (1989) Variation in growth rate and reproduction of the bryozoan Bugula neritina. Biol Bull 177:277-286

Kim K (1996) Patterns and controls of modular growth in gorgonian corals. PhD thesis, State University of New York at Buffalo

Kim K, Lasker HR (1997) Flow-mediated resource competition in the suspension feeding gorgonian Plexaura homomalla (Esper). J Exp Mar Biol Ecol 215:49-64

Kinzie RA, Sarmiento T (1986) Linear extension rate is independent of colony size in the coral Pocillopora damicornis. Coral Reefs 4:177-181

Kojis BL, Quinn NJ (1981) Aspects of sexual reproduction and larval development in the shallow water hermatypic coral, Goniastrea australensis (Edwards and Haime 1857). Bull Mar Sci 31:558-573

Kojis BL, Quinn NJ (1985) Puberty in Goniastrea favulus age or size limited? Proc 5th Intl Coral Reef Congress, Tahiti 4:289-293

Lasker HR, Coffroth MA (1983) Octocoral distributions at Carrie Bow Cay, Belize. Mar Ecol Prog Ser 13:21-28

Lasker HR, Brazeau DA, Calderon J, Coffroth MA, Coma R, Kim $K$ (1996) In situ rates of fertilization among broadcast spawning gorgonian corals. Biol Bull 190:45-55 
Levitan DR (1995) The ecology of fertilization in freespawning invertebrates. In: McEdward L (ed) Ecology of marine invertebrate larvae. CRC Press, Boca Raton, FL, p $123-156$

Potts DC, Done TJ, Isdale PJ, Fisk DA (1985) Dominance of a coral community by the genus Porites (Scleractinia). Mar Ecol Prog Ser 23:79-84

Rinkevich B, Loya Y (1979) The reproduction of the Red Sea coral Stylophora pistillata. II. Synchronization in breeding and seasonality of planulae shedding. Mar Ecol Prog Ser $1: 145-152$

Robertson DR (1987) Responses of two coral reef toadfishes (Batrachoididae) to the demise of their primary prey, the sea urchin. Copeia 3:637-642

Soong K (1993) Colony size as a species character in massive reef corals. Coral Reefs 12:77-83

Editorial responsibility: Ron Karlson (Contributing Editor), Newark, Delaware, USA
Soong K, Lang JC (1992) Reproductive integration in reef corals. Biol Bull 183:418-431

Szmant AM (1986) Reproductive ecology of Caribbean reef corals. Coral Reefs 5:43-53

Vance RR (1973) On reproductive strategies in marine benthic invertebrates. Am Nat 107:339-352

Van Veghel MLJ, Kahmann MEH (1994) Reproductive characteristics of the polymorphic Caribbean reef building coral Montastrea annularis. II. Fecundity and colony structure. Mar Ecol Prog Ser 109:221-227

Ward S (1995) Two patterns of energy allocation for growth, reproduction and lipid storage in the scleractinian coral Pocillopora damicornis. Coral Reefs 14:87-90

Yoshioka PM. Yoshioka BB (1991) A comparison of the survivorship and growth of shallow-water gorgonian species of Puerto Rico. Mar Ecol Prog Ser 69:253-260

Submitted: August 26, 1998; Accepted: September 19, 1999 Proofs received from author(s): March 27, 2000 